KEYWORDS

Employment

Labour market

Employment creation

Households

Family

Family income

Social conditions

Employment statistics

Econometric models

Argentina
Fernando Groisman

National Council of Scientific and Technical Research (CONICET) and University of Buenos Aires (UBA)

œ fgroisman@conicet.gov.ar
CEPAL REVIEW 104 AUGUST 2011

\section{Argentina: households and labour market changes (2004-2009)}

\author{
Fernando Groisman
}

$\mathrm{T}$

his article outlines the changes that occurred in employment between 2004 and 2009 and reviews the links that households established with the labour market. An increase in the number of jobs registered with the social security system was one of the key features of the period. Moreover, half of the rise in the observed employment rate represented jobs obtained by household members other than heads of household. The increase in protected employment also benefited social sectors that have traditionally been neglected, although there are factors that restrict the access of certain population groups to such jobs. Another research finding is that if the head of the household has a protected job, other household members have better chances of gaining a similar job themselves. 


\section{I}

\section{Introduction}

Any review of the social changes that have occurred in Argentina over the last few years must inevitably focus on the labour market, given the sustained recovery in the level of employment and progressive rebuilding of labour incomes that have taken place. A direct way to do this is by examining the trend of employment indicators that summarize the functioning of this market. ${ }^{1}$ The research is also enhanced when households are used as the unit of analysis, since it then becomes possible to study people's patterns of participation in economic activity, in relation to the positions they occupy in the family structure or their contribution to the household's monetary income, or both, among other potential dimensions of analysis. This article used this relatively less common approach, ${ }^{2}$ which provided new information on the type of linkages households established with the labour market during the economic upswing phase.

The characteristics of the economic recovery process following the 2001 crisis also make the proposed analysis timely. In addition to increases in the volume of the employment and higher wages, as mentioned above, another characteristic is the sharp rise in the number of jobs registered with the social security system. Such jobs represent higher quality employment, because, having been declared by employers, they enjoy the protection provided by labour laws; and persons working in those jobs also receive higher wages than their counterparts in precarious jobs. In the five-year period 2004-2009, the number of registered workers increased by $44.1 \%$, whereas the number of workers in unregistered jobs grew by $6.8 \%$ (see table 1 ). The rate of growth of protected employment distinguishes this stage from previous episodes of recomposition of the level of economic activity, which have succeeded one another since the mid-1970s at least, when new employment mainly represented precarious jobs. Between 1970 and 2001, the

\footnotetext{
$\square$ The author is grateful to an anonymous referee for comments made on a previous version of this article. Any remaining error or omission is the author's exclusive responsibility.

1 There is a direct link between the labour market and the social situation, which has been frequently discussed in the literature. Different approaches to this can be found in the work of Stallings and Weller (2001); Tokman (2006); Márquez and others (2007), among others.

2 Although they had different emphases than those developed in this article, progress from this perspective can also be consulted in Arriagada (2007) and ILO/UNDP (2009).
}

share of unregistered jobs in the employment structure increased by 10 percentage points. ${ }^{3}$

The new labour-market scenario clearly reflects a trend change in the registration of employment relations compared to that prevailing in recent decades. Nonetheless, factors seem to persist in Argentine society that restrict or obstruct access to protected jobs by certain population groups. Although in 2009 the number of registered jobs matched the number of households that mainly depended on the labour income of their members (the ratio had been 0.7 in 2004), ${ }^{4}$ this increase was not generalized throughout the population as a whole.

Investigating why the creation of lower-quality jobs tended to be concentrated among a certain type of household should make it possible to recommend policies aimed at ensuring that economic growth generates higher levels of integration and social cohesion. This is the purpose of the rest of this article.

The information used in this article comes from the Permanent Household Survey (EPH) conducted by the National Institute of Statistics and Censuses (INDEC). The EPH is conducted in Argentina's main cities, and encompasses about $70 \%$ of the total urban population. Since 2003, the survey has collected information continuously, producing quarterly estimates for certain variables and half-yearly estimates for others. This article used the micro-databases corresponding to the first quarters of 2004, 2005, 2006, 2007, 2008 and 2009. The period 2002-2003 was excluded from the analysis, because it corresponded to a period of rebound from the trough of the 2001 crisis in Argentina. ${ }^{5}$ This makes it possible to focus on the changes that occurred in Argentine society once a certain growth threshold had been achieved. The article thus provides an overview of the social situation and the changes that occurred in it in the period 2004-2009.

\footnotetext{
${ }^{3}$ Data for the Greater Buenos Aires conurbation - the only information available for the period considered (Permanent Household Survey (EPH) of the National Institute of Statistics and Censuses (INDEC)).

${ }^{4}$ Calculated as the quotient between registered wage-earning workers and households whose heads were employed or unemployed.

${ }^{5}$ In the first quarter of 2004, gross domestic product (GDP) was slightly below its level in early 2001, before the subsequent abrupt slump. For an analysis of the macroeconomic characteristics of the period, see Cetrángolo, Heymann and Ramos (2007).
} 
The article consists of five sections. Section II describes the functioning of the labour market during the period under analysis, while section III provides evidence that illustrates the degree and type of household dependence on the labour market. Section IV characterizes the Argentine social situation, classifying households by income sources and the occupational status of their members. Section V estimates factors that are decisive for gaining access to registered jobs, using recursive univariate and bivariate probit models. Lastly, section VI presents the conclusions.

\section{II}

\section{The functioning of the labour market}

\section{Activity, employment and unemployment}

Between the first quarter of 2004 and the same period in 2007, labour supply grew by $0.7 \%$ between 2004 and 2005 and then by $2.8 \%$ between 2006 and 2007 . This indicator contracted - falling in absolute terms- during the 2007-2008 biennium, before rising again between then and 2009 (see table 1). In the three-year period 2004-2007, labour supply grew by less than job creation, as reflected in a steady decline in the unemployment rate, which dropped from $14 \%$ to $10 \%$ between the first quarters of 2004 and 2007. The decrease in the under-use of the labour force persisted even when job creation slowed down between 2007 and 2008; and the trend in the number of persons employed prevented unemployment growing in that period. By the third quarter of 2009, employment started to grow again, matched by labour supply. This labour-market panorama was consistent with the trend of gross domestic product (GDP) which grew at rates of around 8\% and 9\% in the three years between 2004 and 2007, before resuming a more modest growth path, reflecting the effects of the international economic crisis. ${ }^{6}$

The sector trend of employment shows the buoyancy of construction and domestic service, where the proportion of workers with low levels of education is traditionally very high. In 2007, the number of people employed in the first of these activity sectors was $30.3 \%$ above the 2004 figure, whereas in the second, the increase was $24.7 \%$. Manufacturing industry, transport and communications, and modern services also posted significant job growth (14.6\%, $14 \%$ and $18 \%$, respectively). Understandably, the reduction in job creation between 2007 and 2008 was reflected in sectors of activity that had grown

6 The uneven scale of the crisis in the labour markets of developed and developing countries is described in ILO (2009). vigorously in the preceding years, such as construction and domestic service, along with commerce and social services: education and health (see table 1).

In the five-year period being studied, employment growth mostly reflected the creation of wage-earning jobs. Between the start and end of this period, the number of wage earners increased by $28 \%$, while non-wage-earning employment increased by $5.8 \%$ (see table 1 ). Moreover, most wage-earning jobs were registered with the social security system. Between the start and end of the 20042009 cycle, these workers increased by $44.1 \%$, while the number of unregistered workers rose by $6.8 \%$, thereby showing that employment conditions improved through the twin channels of higher employment and better quality jobs. It should also be noted that the number of unregistered wage earners grew only up to 2007, posting a $12.1 \%$ cumulative increase with respect to the 2004 figure, before declining in absolute terms in the following year, and staying at that level until 2009. ${ }^{7}$

Among other factors, the sanction of a new labour regime in 2004, which encompassed most of the main labour-protection principles that had been repealed by successive amendments to the 1974 Employment Contract Law (Ley de Contrato de Trabajo), certainly affected this result by encouraging employers to register employment contracts. ${ }^{8}$ The implementation of employment control and inspection mechanisms, together with more intensive union activity and the activation of collective bargaining

\footnotetext{
7 The slowdown in job creation at the expense of unregistered jobs combined with an increase in the registration rate. This is interesting because Argentina's economic history shows that the proportion of protected jobs has often fallen at times of economic uncertainty. The explanation for this probably stems from the weak effects that the international financial crisis ultimately had on local productive activity.

8 For a discussion of the employment regime in Argentina, see Goldín (2008).
} 
Selected labour market indicators, 2004-2009

(Total urban agglomerates)

\begin{tabular}{|c|c|c|c|c|c|c|}
\hline & Q1 2004 & Q1 2005 & Q1 2006 & Q1 2007 & Q1 2008 & Q1 2009 \\
\hline Total economically active & 100 & 100.7 & 102.6 & 105.5 & 104.8 & 107.5 \\
\hline Total economically active (1) & 100 & 102.2 & 105.2 & 109.7 & 109.9 & 113.0 \\
\hline Total employed & 100 & 102.3 & 106.2 & 111.1 & 112.1 & 114.9 \\
\hline Total employed (1) & 100 & 104.2 & 109.4 & 116.5 & 118.6 & 121.9 \\
\hline Total wage earners (1) & 100 & 105.8 & 112.8 & 120.9 & 125.3 & 128.0 \\
\hline Registered wage earners & 100 & 105.0 & 116.5 & 127.7 & 139.3 & 144.1 \\
\hline Unregistered wage earners (1) & 100 & 106.8 & 107.9 & 112.1 & 106.7 & 106.8 \\
\hline Non wage earners & 100 & 99.9 & 100.5 & 104.6 & 101.1 & 105.8 \\
\hline Employment plans & 100 & 74.1 & 57.9 & 32.0 & 14.7 & 10.2 \\
\hline \multicolumn{7}{|l|}{ Employed } \\
\hline Industry & 100 & 111.6 & 111.4 & 114.6 & 117.7 & 119.6 \\
\hline Construction & 100 & 99.9 & 113.3 & 130.3 & 125.1 & 133.3 \\
\hline Domestic service & 100 & 111.3 & 119.0 & 124.7 & 124.9 & 126.5 \\
\hline Commerce & 100 & 99.7 & 102.0 & 109.5 & 109.3 & 110.5 \\
\hline Transport & 100 & 107.2 & 108.5 & 114.0 & 116.6 & 121.8 \\
\hline Social services & 100 & 102.5 & 105.4 & 106.0 & 106.0 & 106.9 \\
\hline Public sector & 100 & 94.2 & 101.4 & 98.2 & 101.3 & 107.1 \\
\hline Modern services & 100 & 106.3 & 108.5 & 118.0 & 117.1 & 125.5 \\
\hline \multicolumn{7}{|l|}{ Employed (1) } \\
\hline Low education level & 100 & 103.3 & 103.8 & 109.9 & 107.5 & 110.1 \\
\hline High education level & 100 & 104.9 & 114.5 & 122.4 & 128.6 & 132.6 \\
\hline \multicolumn{7}{|l|}{ Non-wage earners } \\
\hline Low education level & 100 & 95.9 & 97.1 & 97.8 & 93.5 & 97.1 \\
\hline High education level & 100 & 104.2 & 104.2 & 112.1 & 109.4 & 115.4 \\
\hline \multicolumn{7}{|l|}{ Wage earners (1) } \\
\hline Low education level & 100 & 106.5 & 106.8 & 115.1 & 113.6 & 115.7 \\
\hline High education level & 100 & 105.2 & 117.9 & 125.8 & 135.0 & 138.3 \\
\hline \multicolumn{7}{|l|}{ Registered wage earners } \\
\hline Low education level & 100 & 104.5 & 111.3 & 122.3 & 129.5 & 130.3 \\
\hline High education level & 100 & 105.3 & 119.1 & 130.3 & 144.2 & 151.0 \\
\hline \multicolumn{7}{|l|}{ Unregistered wage earners (1) } \\
\hline Low education level & 100 & 108.0 & 103.6 & 110.1 & 102.6 & 105.5 \\
\hline High education level & 100 & 105.0 & 114.9 & 115.4 & 113.6 & 108.9 \\
\hline \multicolumn{7}{|l|}{ Position in the household } \\
\hline Head & 100 & 106.5 & 109.3 & 116.2 & 117.6 & 120.0 \\
\hline Spouse & 100 & 105.5 & 113.6 & 121.2 & 130.9 & 134.6 \\
\hline Other members & 100 & 104.8 & 118.0 & 128.4 & 133.9 & 136.7 \\
\hline
\end{tabular}

Source: Prepared on the basis of EPH-INDEC data.

(1) Excludes employment plans.

instruments during these years, probably also have had an influence in the same direction.

Another feature of the functioning of the labour market during the period was a steady reduction in the number of workers covered by employment plans. ${ }^{9}$ Only

\footnotetext{
${ }^{9}$ In 2002, a conditional income-transfer programme was implemented to mitigate the effects of unemployment, known as the Unemployed Heads of Household Plan (Plan Jefas y Jefes de Hogar Desocupados), which eventually accounted for about $7 \%$ of total employment.
}

$10.2 \%$ of beneficiaries in the first quarter of 2004 were still beneficiaries in the first quarter of 2009.

Consideration of the position occupied by persons in the household - heads of household, their spouses, and other members (mostly children)—, reveals a variety of paths. Between the beginning and end of the period, the categories showing the largest increases in wage-earning employment were spouses $(34.6 \%)$ and other family members $(36.7 \%)$, while household heads displayed an increase of $20 \%$ between the start 
and end of the five-year period (see table 1). As would be expected, a similar trend applies to registered jobs. This behaviour justifies evaluating the distribution of protected jobs among households; in other words, evaluating the determinants of access to these jobs by household members who are not heads of family. That issue is considered in section V.

\section{The educational level of the labour force}

Workers with a higher education level (secondary education complete) benefited most from the greater job opportunities. The number of wage earners that had completed this education level increased by $38.3 \%$ between 2004 and 2009, whereas those with low education (who did not complete the middle education level) grew by $15.7 \%$ in that period, having already achieved $15.1 \%$ growth by 2007 (see table 1). Access to jobs registered with social security grew by a similar percentage. The number of wage earners of higher educational levels in such jobs increased by $51 \%$ between the start and end of the period, while those with low education levels in similar jobs increased by $30.3 \%$. The few job opportunities available to individuals with low education levels is also reflected in the economic participation of this group. The activity rate among those with low education levels barely exceeded $40 \%$ : the precise figure was $42.3 \%$, or
$41.9 \%$ if employment plan beneficiaries are excluded from the calculation, whereas the equivalent figures for more educated individuals were $71.9 \%$ and $71.7 \%$ (with and without employment plans, respectively) (see table 2). This disparity in economic participation by the two population groups can be viewed partly as an expression of discouragement among those who fail to obtain a job. This point will be discussed further below, although it should be noted that the trend of the activity rate is also compatible with this interpretation. Precisely between 2004 and 2009, the economic participation of individuals with low levels of education declined, but this did not happen with individuals of higher education levels.

The uneven trend of access to employment according to a person's education level seems to have reflected both demand and supply-side factors. The availability of surplus labour in the Argentine economy in the first few years of this decade would have enabled firms to raise the education threshold needed for the new jobs created. Given the persistence of a wide gap in registration rates according to wage earners' education levels, this would probably have occurred more frequently for better quality jobs, although the growth of such jobs affected all sectors of activity (see table 3 ). It should be noted that this would have happened even though jobseekers had educational credentials in excess of those specified

TABLE 2

Activity and unemployment rate (total and by education level), 2004-2009

(Total urban agglomerates) (Percentages)

\begin{tabular}{|c|c|c|c|c|c|c|}
\hline & Q1 2004 & Q1 2005 & Q1 2006 & Q1 2007 & Q1 2008 & Q1 2009 \\
\hline \multicolumn{7}{|l|}{ Activity rate } \\
\hline Total & 55.2 & 55.0 & 55.3 & 55.5 & 54.4 & 55.2 \\
\hline Low education level & 44.8 & 44.9 & 43.7 & 43.5 & 41.7 & 42.3 \\
\hline High education level & 71.4 & 70.6 & 72.2 & 72.2 & 71.2 & 71.9 \\
\hline \multicolumn{7}{|l|}{ Unemployment rate } \\
\hline Total & 14.3 & 12.9 & 11.3 & 9.7 & 8.3 & 8.4 \\
\hline Low education level & 14.4 & 13.9 & 12.8 & 10.5 & 9.0 & 9.1 \\
\hline High education level & 14.2 & 12.0 & 10.0 & 9.0 & 7.8 & 7.8 \\
\hline \multicolumn{7}{|c|}{$\begin{array}{l}\text { With employment plan beneficiaries } \\
\text { considered as inactive }\end{array}$} \\
\hline \multicolumn{7}{|l|}{ Activity rate } \\
\hline Total & 52.2 & 52.9 & 53.6 & 54.6 & 54.0 & 54.9 \\
\hline Low education level & 40.9 & 41.8 & 41.5 & 42.3 & 41.2 & 41.9 \\
\hline High education level & 70.0 & 69.7 & 71.4 & 71.7 & 71.0 & 71.7 \\
\hline \multicolumn{7}{|l|}{ Unemployment rate } \\
\hline Total & 15.1 & 13.5 & 11.7 & 9.9 & 8.4 & 8.4 \\
\hline Low education level & 15.7 & 14.9 & 13.5 & 10.8 & 9.1 & 9.2 \\
\hline High education level & 14.5 & 12.1 & 10.1 & 9.0 & 7.8 & 7.8 \\
\hline
\end{tabular}

Source: Prepared on the basis of EPH-INDEC data. 


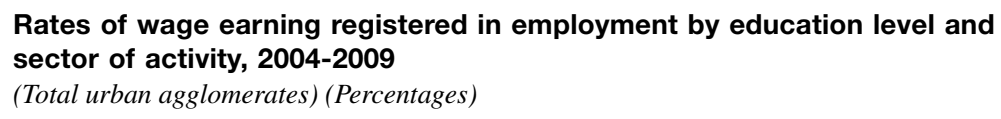

\begin{tabular}{|c|c|c|c|c|c|c|}
\hline & Q1 2004 & Q1 2005 & Q1 2006 & Q1 2007 & Q1 2008 & Q1 2009 \\
\hline \multicolumn{7}{|l|}{ Position in the household and education level } \\
\hline Head of household with low education level & 54.3 & 51.9 & 55.0 & 54.9 & 57.0 & 57.9 \\
\hline Head of household with high education level & 76.3 & 76.2 & 78.0 & 77.7 & 79.8 & 81.3 \\
\hline Spouse with low education level & 26.4 & 28.3 & 31.0 & 35.8 & 41.0 & 37.4 \\
\hline Spouse with high education level & 78.1 & 77.1 & 75.4 & 79.0 & 78.6 & 82.0 \\
\hline Other members with low education level & 25.5 & 25.1 & 27.7 & 28.7 & 34.0 & 33.4 \\
\hline Other members with higher education level & 55.6 & 57.1 & 58.5 & 61.8 & 65.8 & 66.2 \\
\hline \multicolumn{7}{|l|}{ Sector of activity } \\
\hline Industry & 66.6 & 64.5 & 65.7 & 67.7 & 71.1 & 72.0 \\
\hline Construction & 23.8 & 21.1 & 25.4 & 32.1 & 35.8 & 40.5 \\
\hline Domestic service & 6.4 & 4.9 & 6.6 & 9.5 & 12.6 & 12.7 \\
\hline Commerce & 48.2 & 49.0 & 51.7 & 53.5 & 55.2 & 54.6 \\
\hline Transport & 50.0 & 51.6 & 56.4 & 60.9 & 62.5 & 60.4 \\
\hline Social services & 67.1 & 66.4 & 69.1 & 67.8 & 71.6 & 74.0 \\
\hline Public sector & 90.0 & 91.4 & 90.5 & 91.6 & 92.9 & 92.7 \\
\hline Modern services & 64.0 & 65.3 & 70.9 & 70.1 & 73.5 & 73.7 \\
\hline
\end{tabular}

Source: Prepared on the basis of EPH-INDEC data.

Excludes employment plan beneficiaries.

as requirements for the post in question. Given the sector pattern of employment growth, based on labour-intensive import-substituting industries, construction and, to a lesser extent, services, the hypothesized prevalence of a genuine demand for skills as a dominant feature, seems to be less well founded. Moreover, the employment chances for lower-education workers also could have been the result of other factors, including the adverse effects of socioeconomic residential segregation: stigmatization based on place of residence, public transport deficits, the circulation of information on job vacancies, among others. ${ }^{10}$

The trend of employment by education level, position in the household and occupational category (registered or unregistered wage earner) is partly influenced by differential labour-market participation rates by activity sector. About $40 \%$ of heads of household with low education levels were employed in construction, domestic service (basically women heads of household in this case) and commerce. The equivalent figure was less than $20 \%$ in the case of heads of household with higher education levels (see table 4).

10 On this point, see Kaztman (2007); Groisman (2008 and 2010) and Sabatini and Brian (2008).

\section{The increase in the registered employment rate}

The factors driving the increase in protected employment can be estimated using the evidence presented in subsections 1 and 2 . The change in the rate of registration of employment between 2004 and 2009 can be explained by two factors: firstly, changes in the composition of wage earners in terms of their education level and position in the household (structure effect); and secondly, variations in the specific rates for each group (rate or propensity effect). The exercise simulated the rate of registered employment in 2009 if the structure of wage earners had not varied by education level or household position, on the one hand, or on the rates of registration in each of the groups considered, on the other. The differences between the new rates thus obtained and the rate observed in 2009 confirms the effects described above.

The calculation performed showed that of the 7.2 percentage points (p.p.) by which the registration rate increased, the structure effect had a marginal incidence of 0.6 p.p. Consequently, the overall variation was mostly explained by the change in registration rates (see table 5).

In particular, of the remaining 6.4 p.p. (after deducting the structural and residual effects) 4.2 percentage points reflect the increase in the rates of 
TABLE 4

Sector distribution of employment of heads of household by education level, 2004-2009

(Total urban agglomerates) (Percentages)

\begin{tabular}{|c|c|c|c|c|c|c|}
\hline & Q1 2004 & Q1 2005 & Q1 2006 & Q1 2007 & Q1 2008 & Q1 2009 \\
\hline \multicolumn{7}{|c|}{ Head of household with low education level } \\
\hline Industry & 21.4 & 20.9 & 20.3 & 20.4 & 20.3 & 18.7 \\
\hline Construction & 10.2 & 11.2 & 13.1 & 14.5 & 12.2 & 12.5 \\
\hline Domestic service & 12.3 & 12.6 & 14.0 & 13.3 & 14.0 & 13.9 \\
\hline Commerce & 18.5 & 17.3 & 16.1 & 16.6 & 16.9 & 18.2 \\
\hline Transport & 11.3 & 12.6 & 10.9 & 12.0 & 11.8 & 12.4 \\
\hline Social services & 9.1 & 8.5 & 8.8 & 8.5 & 8.6 & 8.4 \\
\hline Public sector & 11.5 & 10.2 & 10.8 & 9.1 & 10.6 & 11.1 \\
\hline Modern services & 5.8 & 6.8 & 6.0 & 5.6 & 5.5 & 4.9 \\
\hline Total & 100.0 & 100.0 & 100.0 & 100.0 & 100.0 & 100.0 \\
\hline \multicolumn{7}{|c|}{ Head of household with high education level } \\
\hline Industry & 17.8 & 16.6 & 16.3 & 14.5 & 15.9 & 16.5 \\
\hline Construction & 2.9 & 2.2 & 1.8 & 3.4 & 3.3 & 4.4 \\
\hline Domestic service & 2.5 & 3.2 & 3.8 & 3.1 & 3.2 & 2.7 \\
\hline Commerce & 15.4 & 15.6 & 16.0 & 15.3 & 16.6 & 15.2 \\
\hline Transport & 7.9 & 8.1 & 7.5 & 8.1 & 7.2 & 6.9 \\
\hline Social services & 12.7 & 12.9 & 14.0 & 12.9 & 13.7 & 13.8 \\
\hline Public sector & 27.5 & 27.8 & 29.2 & 29.1 & 27.9 & 27.8 \\
\hline Modern services & 13.3 & 13.7 & 11.5 & 13.6 & 12.2 & 12.8 \\
\hline Total & 100.0 & 100.0 & 100.0 & 100.0 & 100.0 & 100.0 \\
\hline
\end{tabular}

Source: Prepared on the basis of EPH-INDEC data.

TABLE 5

Breakdown of the variation in the rate of registered employment, 2004-2009 (Percentages)

\begin{tabular}{|c|c|c|c|c|c|c|}
\hline & Q1 2004 & Q1 2005 & Q1 2006 & Q1 2007 & Q1 2008 & Q1 2009 \\
\hline $\begin{array}{l}\text { Rate of registered employment (excluding } \\
\text { employment plan beneficiaries) }\end{array}$ & 56.8 & 56.4 & 58.7 & 60.0 & 63.2 & 64.0 \\
\hline Annual difference (p.p.) & & -0.4 & 2.3 & 1.3 & 3.2 & 0.8 \\
\hline Difference between extremes & & & & & & 7.2 \\
\hline $\begin{array}{l}\text { Education structure in effect and position } \\
\text { in the household }\end{array}$ & & & & & & 0.6 \\
\hline \multicolumn{7}{|l|}{ Effects of specific rates by groups } \\
\hline Head of household with low education level & & & & & & 0.9 \\
\hline Head of household with high education level & & & & & & 1.2 \\
\hline Spouse with low education level & & & & & & 0.9 \\
\hline Spouse with high education level & & & & & & 0.5 \\
\hline Other members with low education level & & & & & & 1.0 \\
\hline Other members of higher education level & & & & & & 1.9 \\
\hline Total effects of specific rates by groups & & & & & & 6.4 \\
\hline Residual & & & & & & 0.15 \\
\hline
\end{tabular}

Source: Prepared on the basis of EPH-INDEC data. 
registration among household members other than heads. The contribution by spouses was 1.4 p.p. -0.9 p.p. for those of low education levels and 0.5 p.p. for those with higher education levels. Among other household members (mostly children) 1.9 percentage points were contributed by an increased registration of those with higher education, while one percentage point corresponded to those of low education. The increase in the rate of registration of heads of household $(2.1$ p.p.) was due to a 0.9 p.p. increase among those with high education levels and 1.2 p.p. among those with a low level of education.

The results of this exercise highlight the leading role played by workers who are not heads of their households in the overall improvement of employment quality indicators.

\section{III \\ Dependency on the labour market: an analysis at the household level}

Before characterizing the effect of changes in labour market on Argentina's social structure, the degree to which households depend on the labour incomes of their members needs to be measured.

Table 6 shows that about eight out of every 10 households obtained monetary income as a result of an employment activity undertaken by their members. The proportion of households that depended exclusively on the labour market was $58.6 \%$ in 2004 , dropping to $52.6 \%$ in 2009; while the proportion of households that received non-labour incomes only (mainly pensions of various kinds) remained stable. Both behaviour patterns reflect an expansion of pension-system coverage during this five-year period.

The classification of households according to the education level attained by their heads (Low: up to secondary education incomplete; Medium: Up to higher education incomplete; and High: Higher education complete) also shows that the overall change basically reflected what had happened among lowerincome households.

Although the number of households that received both labour and non-labour incomes increased, the composition of monetary income (between labour and non-labour sources) remained stable overall, with labour income continuing to account for about $80 \%$ of household budgets. This figure is what best reflects the central role played by the labour market in the well-being to which Argentine households can aspire. It should also be noted that the proportion of income obtained from labour sources rises with the level of education of the head of household, which means that households headed by individuals of low education level rely more heavily on income from pensions.
Table 7 shows that two thirds of non-labour income came from pensions, broadly unchanged in the five-year period under analysis; while income obtained from second jobs accounts for a small proportion.

Heads of households are the main household income-earners. Income obtained from the head of household's main occupation accounts for a majority of household income, outweighing all contributions made by other household members together (see table 8). Nonetheless, and in keeping with the employment trend noted in section II, its share declined by 5.6 p.p., from $63.7 \%$ to $57.9 \%$, at the expense of a relative increase in contributions made by the other household members, particularly non-spouses. Although the relative reduction in the income share contributed by heads of household was generalized across all household strata, an analysis by the education level of the head of household reveals a number of differences.

In households headed by persons with low levels of education, the proportion of income contributed by them fluctuated around 50\%, whereas in households with more educated heads, the equivalent figure was around $60 \%$. The second characteristic worth stressing is the smaller contribution made by spouses in households with low-education heads - about $15 \%$ of the household's total labour income, compared to $20 \%$ in the case of households with headed by persons with higher levels of education.

Considering the type of occupational activity (see table 8), the main source of labour income for households in general was registered wage-earning employment: $56.6 \%$ of total household income in 2004 , rising to $61.7 \%$ in 2009. This trend is consistent with the higher registration rate noted earlier. This relative increase 


\begin{tabular}{|c|c|c|c|}
\hline & Q1 2004 & Q1 2007 & Q1 2009 \\
\hline \multicolumn{4}{|l|}{ Distribution of households } \\
\hline \multicolumn{4}{|l|}{ Total households } \\
\hline Receive non-labour income only & 18.9 & 17.6 & 17.6 \\
\hline Receive labour income only & 58.6 & 54.8 & 52.6 \\
\hline Received both types of income & 22.5 & 27.6 & 29.8 \\
\hline Total & 100.0 & 100.0 & 100.0 \\
\hline \multicolumn{4}{|c|}{ Head of household with low education level } \\
\hline Receive non-labour income only & 21.7 & 21.1 & 21.0 \\
\hline Receive labour income only & 55.6 & 47.9 & 43.6 \\
\hline Receive both types of income & 22.7 & 31.1 & 35.5 \\
\hline Total & 100.0 & 100.0 & 100.0 \\
\hline \multicolumn{4}{|c|}{ Head of household with medium education level } \\
\hline Receive labour income only & 61.2 & 60.8 & 60.8 \\
\hline Receive both types of income & 21.8 & 23.8 & 23.2 \\
\hline Total & 100.0 & 99.9 & 100.0 \\
\hline \multicolumn{4}{|c|}{ Head of household with high education level } \\
\hline Receive non-labour income only & 11.7 & 9.4 & 10.0 \\
\hline Receive labour income only & 65.2 & 68.4 & 66.1 \\
\hline Receive both types of income & 23.2 & 22.3 & 24.0 \\
\hline Total & 100.1 & 100.0 & 100.0 \\
\hline \multicolumn{4}{|l|}{ Composition of household income } \\
\hline Labour income & 79.8 & 80.7 & 81.3 \\
\hline Non-labour income & 20.2 & 19.3 & 18.7 \\
\hline Total & 100.0 & 100.0 & 100.0 \\
\hline \multicolumn{4}{|c|}{ Head of household with low education level } \\
\hline Labour income & 75.4 & 75.9 & 76.3 \\
\hline \multicolumn{4}{|c|}{ Head of household with medium education level } \\
\hline Labour income & 80.0 & 81.6 & 83.2 \\
\hline Non-labour income & 20.0 & 18.4 & 16.8 \\
\hline Total & 100.0 & 100.0 & 100.0 \\
\hline \multicolumn{4}{|c|}{ Head of household with high education level } \\
\hline Labour income & 85.9 & 87.0 & 86.4 \\
\hline Non-labour income & 14.1 & 13.0 & 13.6 \\
\hline Total & 100.0 & 100.0 & 100.0 \\
\hline
\end{tabular}

Source: Prepared on the basis of EPH-INDEC data.

occurred at the expense of the contribution provided by precarious wage-earning jobs, which shrank by 4.1 p.p. (from $18.8 \%$ to $14.7 \%$ ). Although this increase in the proportion of income obtained from registered jobs occurred in all three household groups, it was more intense in households headed by persons with a low education level. This reflected the greater relative share of household members other than the head. In particular, in the combination of contributions according to the position of the household and labour-market participation, the contribution made by household heads declined in all occupation categories, with the corresponding gains being concentrated among other household members in registered jobs: 4.1 p.p. for children (from $9.4 \%$ to $13.5 \%$ in 2004 and 2009, respectively) and 2.1 p.p. for spouses (from $10.6 \%$ to $12.7 \%$ in 2004 and 2009, respectively).

Although households in the lower group benefited from access to registered jobs, the gap separating lowerincome households from the rest remained wide in 2009. In the latter group of households, the contribution by registered workers was nine p.p. less than in households 
(Total urban agglomerates) (Percentages)

\begin{tabular}{|c|c|c|c|}
\hline & Q1 2004 & Q1 2007 & Q1 2009 \\
\hline \multicolumn{4}{|l|}{ Total households } \\
\hline Income from main jobs & 93.9 & 93.2 & 93.8 \\
\hline Labour income from second jobs & 6.1 & 6.8 & 6.2 \\
\hline Total labour income & 100.0 & 100.0 & 100.0 \\
\hline Income from pensions & 65.3 & 62.6 & 65.8 \\
\hline Other non-labour income & 34.7 & 37.4 & 34.2 \\
\hline Total non-labour income & 100.0 & 100.0 & 100.0 \\
\hline \multicolumn{4}{|c|}{ Head of household with low education level } \\
\hline Income from main jobs & 94.5 & 94.9 & 95.3 \\
\hline Labour income from second jobs & 5.5 & 5.1 & 4.7 \\
\hline Total labour income & 100.0 & 100.0 & 100.0 \\
\hline Income from pensions & 72.8 & 69.2 & 71.7 \\
\hline Other non-labour income & 27.2 & 30.8 & 28.3 \\
\hline Total non-labour income & 100.0 & 100.0 & 100.0 \\
\hline \multicolumn{4}{|c|}{ Head of household with medium education level } \\
\hline Income from main jobs & 95.8 & 94.6 & 94.9 \\
\hline Labour income from second jobs & 4.2 & 5.4 & 5.1 \\
\hline Total labour income & 100.0 & 100.0 & 100.0 \\
\hline Income from pensions & 53.4 & 56.3 & 56.7 \\
\hline Other non-labour income & 46.6 & 43.7 & 43.3 \\
\hline Total non-labour income & 100.0 & 100.0 & 100.0 \\
\hline \multicolumn{4}{|c|}{ Head of household with high education level } \\
\hline Income from main jobs & 91.2 & 89.5 & 90.7 \\
\hline Labour income from second jobs & 8.8 & 10.5 & 9.3 \\
\hline Total labour income & 100.0 & 100.0 & 100.0 \\
\hline Income from pensions & 64.1 & 54.4 & 63.9 \\
\hline Other non-labour income & 35.9 & 45.6 & 36.1 \\
\hline Total non-labour income & 100.0 & 100.0 & 100.0 \\
\hline
\end{tabular}

Source: Prepared By the authors on the basis of EPH-INDEC data.

headed by persons with high and medium education levels (56.1\% compared to $65.1 \%$ and $65.2 \%$, respectively), and the contribution from unregistered jobs $(22.7 \%)$ was double the proportion in households headed by persons of medium education level $(11.1 \%)$ and nearly three times the level of households in the higher category $(8 \%)$ (see table 8).

This analysis can be enhanced by identifying the income sources on which households depend, and hence the degree to which households can draw on different sources of income. Table 9 shows that between $75.3 \%$ (in 2004) and 73\% (2009) of households obtained their income from a single source (in registered jobs, unregistered jobs, self-employment, or else as employers). This reveals the limited scope available to households to develop strategies enabling them to arrange the type of job to which their members can gain access. The situation in 2009 shows that $41.3 \%$ of households received income exclusively from registered jobs; $16.2 \%$ from unregistered jobs only; $12.3 \%$ from self-employment; and $3.2 \%$ as bosses or employers. There was a sharp reduction (8.2 percentage points) in the number of households that depended only on income from unregistered jobs between 2004 and 2009 (see table 9). In the same period, families depending exclusively on income obtained from self-employment activities decreased by about two p.p. (from $14.1 \%$ to $12.3 \%$ ), whereas the proportion of families obtaining income from jobs registered with social security increased by seven p.p. (from $34.3 \%$ to $41.3 \%$ ). There were no significant changes in the distribution of households by combination of sources. Although the proportion of households depending exclusively on income obtained from registered jobs increased in all three household groups, the increase was greater in those headed by persons with low levels of education. Nonetheless, one third of those households $(31.9 \%)$ were still in that situation in 2009 , compared to $49 \%$ of households headed by a person with a medium level of education, and $53.8 \%$ in households headed by a person with a high level of education. 


\begin{tabular}{|c|c|c|c|}
\hline & Q1 2004 & Q1 2007 & Q1 2009 \\
\hline \multicolumn{4}{|l|}{ Total households } \\
\hline Labour income of unregistered heads & 9.3 & 8.4 & 6.7 \\
\hline Labour income of registered heads & 36.7 & 35.0 & 35.4 \\
\hline Labour income of self-employed heads & 11.0 & 9.8 & 9.4 \\
\hline Labour income of employer heads & 6.7 & 7.7 & 6.4 \\
\hline Labour income of unregistered spouses & 3.7 & 2.5 & 2.5 \\
\hline Labour income of self-employed spouses & 2.9 & 2.8 & 2.9 \\
\hline Labour income of employer spouses & 1.4 & 1.5 & 1.7 \\
\hline Labour income of other unregistered members & 5.8 & 5.8 & 5.6 \\
\hline Labour income of other registered members & 9.4 & 12.2 & 13.5 \\
\hline Labour income of other self-employed members & 2.2 & 2.1 & 2.3 \\
\hline Labour income of other employer members & 0.3 & 0.9 & 0.7 \\
\hline Total & 100.0 & 100.0 & 100.0 \\
\hline Labour income of unregistered heads & 13.3 & 11.5 & 8.7 \\
\hline Labour income of registered heads & 26.6 & 27.5 & 26.9 \\
\hline Labour income of self-employed heads & 12.8 & 10.5 & 9.9 \\
\hline Labour income of employer heads & 3.8 & 4.5 & 3.7 \\
\hline Labour income of unregistered spouses & 5.0 & 3.4 & 3.8 \\
\hline Labour income of registered spouses & 6.4 & 7.4 & 8.9 \\
\hline Labour income of self-employed spouses & 2.9 & 2.4 & 2.6 \\
\hline Labour income of employer spouses & 0.5 & 0.8 & 1.0 \\
\hline Labour income of other unregistered members & 10.5 & 9.8 & 10.3 \\
\hline Labour income of other registered members & 14.8 & 17.7 & 20.2 \\
\hline Labour income of other self-employed members & 3.1 & 3.5 & 3.2 \\
\hline Labour income of other employer members & 0.3 & 1.2 & 0.7 \\
\hline Labour income from main jobs & 100.0 & 100.0 & 100.0 \\
\hline \multicolumn{4}{|l|}{ Head with medium education level } \\
\hline Labour income of self-employed heads & 11.0 & 9.3 & 8.4 \\
\hline Labour income of employer heads & 8.2 & 9.4 & 7.8 \\
\hline Labour income of unregistered spouses & 3.5 & 2.1 & 2.0 \\
\hline Labour income of registered spouses & 12.7 & 13.4 & 14.9 \\
\hline Labour income of self-employed spouses & 2.8 & 2.9 & 3.1 \\
\hline Labour income of employer spouses & 1.6 & 1.4 & 1.7 \\
\hline Labour income of other unregistered members & 3.9 & 4.2 & 3.1 \\
\hline Labour income of other registered members & 7.1 & 11.6 & 10.4 \\
\hline Labour income of other self-employed members & 2.0 & 1.4 & 1.5 \\
\hline Labour income of other employer members & 0.3 & 0.7 & 1.0 \\
\hline Labour income from main jobs & 100.0 & 100.0 & 100.0 \\
\hline \multicolumn{4}{|l|}{ Head with high education level } \\
\hline Labour income of unregistered heads & 5.5 & 6.0 & 4.6 \\
\hline Labour income of registered heads & 47.6 & 42.9 & 41.9 \\
\hline Labour income of self-employed heads & 8.8 & 9.6 & 9.7 \\
\hline Labour income of employer heads & 9.2 & 10.4 & 8.4 \\
\hline Labour income of unregistered spouses & 1.9 & 1.9 & 1.4 \\
\hline Labour income of registered spouses & 14.0 & 14.2 & 15.3 \\
\hline Labour income of self-employed spouses & 2.9 & 3.4 & 3.1 \\
\hline Labour income of employer spouses & 2.6 & 2.5 & 2.9 \\
\hline Labour income of other unregistered members & 1.6 & 2.1 & 2.0 \\
\hline Labour income of other registered members & 4.5 & 5.2 & 7.9 \\
\hline Labour income of other self-employed members & 1.2 & 1.1 & 2.2 \\
\hline Labour income of other employer members & 0.3 & 0.7 & 0.4 \\
\hline Labour income from main jobs & 100.0 & 100.0 & 100.0 \\
\hline
\end{tabular}

Source: prepared by the authors on the basis of EPH-INDEC data. 
Distribution of households by employment activity of their members, 2004, 2007 and 2009

(Total urban agglomerates) (Percentages)

\begin{tabular}{|c|c|c|c|}
\hline & Q1 2004 & Q1 2007 & Q1 2009 \\
\hline Unregistered only & 24.4 & 19.5 & 16.2 \\
\hline Self-employed only & 14.1 & 12.7 & 12.3 \\
\hline Employers only & 2.5 & 2.8 & 3.3 \\
\hline Registered only & 34.3 & 37.4 & 41.3 \\
\hline Total single source & 75.3 & 72.3 & 73.0 \\
\hline With unregistered and self-employed & 6.0 & 4.9 & 4.2 \\
\hline With unregistered and registered & 9.1 & 11.3 & 10.8 \\
\hline With unregistered and employers & 1.0 & 1.3 & 0.9 \\
\hline With registered and employers & 1.0 & 1.4 & 1.5 \\
\hline With a registered and self-employed & 5.4 & 6.5 & 6.7 \\
\hline With employers and self-employed & 0.6 & 0.4 & 0.4 \\
\hline Total two different sources & 23.1 & 25.9 & 24.5 \\
\hline With employers, self-employed and registered & 0.0 & 0.1 & 0.1 \\
\hline With employers, self-employed and unregistered & 0.1 & 0.2 & 0.2 \\
\hline With registered, self-employed and unregistered & 1.2 & 1.2 & 1.6 \\
\hline With registered, employers and unregistered & 0.2 & 0.3 & 0.2 \\
\hline Total three different sources & 1.5 & 1.8 & 2.1 \\
\hline With registered, employers, unregistered and self-employed & 0.0 & 0.0 & 0.0 \\
\hline Total & 100 & 100 & 100 \\
\hline
\end{tabular}

Source: Prepared on the basis of EPH-INDEC data.

\section{An approach to the change in the social situation of Argentina}

Based on the results discussed above, the population was classified in different groups according to three dimensions summarizing the degree of dependency of households with respect to the labour market:

(i) The share of labour income in the household's total monetary income;

(ii) The head of household's employment category; and

(iii) The presence of other household members employed in registered jobs.

The trends outlined in the foregoing sections justify the criteria used for this classification. In particular, it will be remembered that labour income was the main component of households' monetary income, and that the head of household made the largest contribution. It was also shown that job registration was more intensive among non-head household members. Combining these criteria made it possible to define a typology of households that provides a succinct panorama of the social situation and how it has changed in the period 2004-2009.

Nine groups were formed which, while not representing a linear ranking, reflect different degrees of social inclusion/exclusion (see table 10). The first four groups encompass households showing a high level of social vulnerability or greater exposure to social risk. The first two groups include families in which lowquality employment was either the only income source (group 1), or the majority source - over 50\% of total household income (group 2). In fact in both groups the head of household was neither employed in a registered job nor an employer; and the households in question did not have other members in protected wage-earning jobs. While the two groups accounted for $36 \%$ of the population in 2004 their share had dropped to $26.1 \%$ in 2009 . This significant reduction was entirely due to what happened in the first of the groups (those with labour 


\begin{tabular}{|c|c|c|c|c|c|c|c|}
\hline Groups & Definition & Q1 2004 & Q1 2005 & Q1 2006 & Q1 2007 & Q1 2008 & Q1 2009 \\
\hline 1 & $\begin{array}{l}\text { Depends exclusively on the labour market, head } \\
\text { of household is not employer or registered wage } \\
\text { earner, and there are no registered members in } \\
\text { the household }\end{array}$ & 26.8 & 25.2 & 21.4 & 17.4 & 15.5 & 14.7 \\
\hline 2 & $\begin{array}{l}\text { Does not depend exclusively on the labour } \\
\text { market, head of household is not employer or } \\
\text { registered wager on and there are no registered } \\
\text { members in the household }\end{array}$ & 9.2 & 9.7 & 11.7 & 11.6 & 11.4 & 11.4 \\
\hline 3 & No employed household members & 10.8 & 10.2 & 10.2 & 9.8 & 9.7 & 9.9 \\
\hline 4 & $\begin{array}{l}\text { Depends on the labour market on a secondary } \\
\text { basis }\end{array}$ & 6.3 & 7.1 & 6.0 & 6.8 & 6.3 & 6.0 \\
\hline 5 & $\begin{array}{l}\text { Head of household is a registered wage earner } \\
\text { and there are no other household members with } \\
\text { this status }\end{array}$ & 21.3 & 21.7 & 21.7 & 22.4 & 22.9 & 22.2 \\
\hline 6 & $\begin{array}{l}\text { Head of household is an unregistered wage } \\
\text { earner or not employed, and there are other } \\
\text { registered wage earners in the household }\end{array}$ & 8.3 & 8.9 & 9.4 & 11.0 & 11.8 & 12.5 \\
\hline 7 & $\begin{array}{l}\text { Head of household is self-employed and there are } \\
\text { other registered wage earners in the household }\end{array}$ & 3.9 & 3.5 & 4.0 & 4.3 & 4.3 & 4.8 \\
\hline 8 & $\begin{array}{l}\text { Head of household is a registered wage earner } \\
\text { and there are other registered wage earners in } \\
\text { the household }\end{array}$ & 9.4 & 9.8 & 11.5 & 12.0 & 13.3 & 14.0 \\
\hline \multirow[t]{2}{*}{9} & Head of household is an employer & 3.9 & 3.9 & 4.1 & 4.7 & 4.9 & 4.6 \\
\hline & Total & 100 & 100 & 100 & 100 & 100 & 100 \\
\hline
\end{tabular}

Source: Prepared on the basis of EPH-INDEC data.

incomes only), which saw their relative weight reduced by around 12 p.p. (from $26.8 \%$ to $14.7 \%$ between 2004 and 2009, respectively). In the same period, group 2 increased its relative weight by 2.2 p.p. (from $9.2 \%$ to $11.4 \%$ ) which is consistent with the higher rates of retirement among lower-income sectors.

Groups 3 and 4 encompass individuals living in households for which the prevailing monetary incomes came from non-labour sources - essentially pensions of various kinds, as noted above. The joint share of the two groups remained virtually unchanged around $16 \%$. Group 5 consists of members of households whose head was the only person with a protected job. This group of households accounted for just over $20 \%$ of the total population, and grew by about one percentage point between the start and end of the period. Group 6, unlike the previous one, included households that have other members in registered jobs, but subject to the condition that the head of household was either unemployed or working in a precarious job. The relative share of this segment grew by 4.2 p.p., from $8.3 \%$ in 2004 to $12.5 \%$ in
2009 , reflecting the pronounced effect of the registration of jobs held by non-head household members. Group 7 was defined similarly to the previous group, except that the head of household was self-employed. In this case, the increase was less than one p.p. between the start and end of the five-year period. Group 8 included all households whose head was in a registered job and which also had another family member working in a registered job. This segment, which accounted for $9.4 \%$ of the population in 2004, had grown to $14 \%$ by the end of the period. Lastly, group 9 comprises households headed by a person working as a boss or employer, which accounted for between $3.9 \%$ and $4.6 \%$.

One way to approach a validation of the proposed classification is by comparing it with a series of sociodemographic characteristics linked to situations of social vulnerability (see table 11).

The table reveals a clear correspondence between the ranking of the social groups constructed and per capita family income. Groups 1 and 2 have a value below average income (67\% and 68\%, respectively). Groups 
TABLE 11

Selected characteristics of the constructed household groups (Q1 2009)

(Total urban agglomerates)

\begin{tabular}{|c|c|c|c|c|c|c|c|c|c|c|c|}
\hline Groups & $\begin{array}{l}\text { Per capita } \\
\text { income gap } \\
\text { in relation to } \\
\text { the average }\end{array}$ & $\begin{array}{l}\text { Household } \\
\text { size }\end{array}$ & $\begin{array}{l}\text { Number of } \\
\text { pensioners }\end{array}$ & $\begin{array}{l}\text { Percentages } \\
\text { of } \\
\text { households } \\
\text { headed by } \\
\text { women }\end{array}$ & $\begin{array}{c}\text { Percentages } \\
\text { of } \\
\text { households } \\
\text { with low } \\
\text { income } \\
\text { heads }\end{array}$ & $\begin{array}{l}\text { Employment } \\
\text { rate }\end{array}$ & $\begin{array}{l}\text { Children } \\
\text { under } \\
\text { three } \\
\text { years of } \\
\text { age }\end{array}$ & $\begin{array}{c}\text { Percentages } \\
\text { employment } \\
\text { in industry }\end{array}$ & $\begin{array}{l}\text { Percentages } \\
\text { employment } \\
\text { in } \\
\text { construction }\end{array}$ & $\begin{array}{c}\text { Percentages } \\
\text { employment } \\
\text { in domestic } \\
\text { service }\end{array}$ & $\begin{array}{l}\text { Percentages } \\
\text { employment } \\
\text { in commerce }\end{array}$ \\
\hline 1 & 0.67 & 3.3 & 0.0 & 28.5 & 59.4 & 56.5 & 0.62 & 12.2 & 15.5 & 13.5 & 29.9 \\
\hline 2 & 0.68 & 4.1 & 0.2 & 40.7 & 73.3 & 48.0 & 0.78 & 10.0 & 18.0 & 13.9 & 32.9 \\
\hline 3 & 0.84 & 1.8 & 0.8 & 54.1 & 62.9 & $\ldots$ & 0.12 & & $\ldots$ & & \\
\hline 4 & 0.95 & 3.1 & 0.4 & 50.8 & 63.1 & 41.9 & 0.38 & 12.2 & $\ddot{8.5}$ & 17.6 & $\ddot{24.8}$ \\
\hline 5 & 1.15 & 3.3 & 0.0 & 25.8 & 39.8 & 52.4 & 0.66 & 18.7 & 6.0 & 6.6 & 18.7 \\
\hline 6 & 0.93 & 4.1 & 0.4 & 47.5 & 65.3 & 53.3 & 0.50 & 16.2 & 7.0 & 7.4 & 21.8 \\
\hline 7 & 1.08 & 4.1 & 0.0 & 14.2 & 50.4 & 71.8 & 0.51 & 13.5 & 10.8 & 5.1 & 24.7 \\
\hline 8 & 1.42 & 3.8 & 0.0 & 16.9 & 31.0 & 70.9 & 0.55 & 14.9 & 4.1 & 1.8 & 15.9 \\
\hline 9 & 1.65 & 3.4 & 0.0 & 13.6 & 33.2 & 66.7 & 0.47 & 18.9 & 8.8 & 2.1 & 32.0 \\
\hline
\end{tabular}

Source: Prepared on the basis of EPH-INDEC data.

3 and 4 were also below average, although the distance from the average was less. Groups 5, 6 and 7 were around the average level, while groups 8 and 9 clearly displayed characteristics that easily exceeded the average value. This evidence corroborates the timely creation, since late 2009, of a non-contributory subsystem known as the Universal Child Allowance for Social Protection (Asignación Universal por Hijo para Protección Social). This program consists of an income transfer for children and adolescents that do not have any other family subsidy provided for by law, and belong to family groups that are unemployed or working in the informal economy and receiving low levels of income. ${ }^{11}$

The household typology also shows a close relation to the education level of the head of household: groups 1 and 2 (59.4\% and $73.3 \%$, respectively) included households headed by persons who had not completed the medium education level; whereas at the other extreme, groups 8

11 On the relation between informality and poverty, see Devicienti, Groisman and Poggi (2010). and 9, the equivalent proportions were $31 \%$ and $33.2 \%$, respectively. In addition, women heads of household were more common in the lower groups, particularly in group $2(40.7 \%)$ whereas in groups 8 and 9 the proportion of households headed by women was $16.9 \%$ and $13.6 \%$, respectively. It is also not surprising that this indicator is high in groups 3 and 4 , since these households consist of retired people or pensioners where women's longer life expectancy is consistent with the prevalence of femaleheaded households (these households are relatively smaller). Employment rates in households in groups 1 and 2 are below those of the higher groups, which jointly reflects the fewer job opportunities available to this group and unequal exposure to the constraints faced by their members in becoming part of labour supply. The presence of children under 10 years of age is also more frequent in group 1 and 2 households. Lastly, in terms of the sector participation achieved by members of these households, there is significant gravitation towards the construction and domestic service sectors, in general, for households in groups 1 and 2 (around $30 \%$ ), compared to rates of around $6 \%$ and $11 \%$ for group 8 and 9 households, respectively. 


\section{V}

\section{Access to better quality jobs}

This section summarizes the foregoing discussion. The clear and sustained increase in jobs registered with the social security system is one of the outstanding features of the Argentine labour market during the period under analysis. As shown in the previous sections, the expansion of protected jobs reached previously neglected social sectors and significantly improved their social situation, unlike what happened in previous economic recovery periods. The vigorous expansion of protected employment in the five-year period 2004-2009 was not generalized, however, so a large proportion of households did not have members working in socialsecurity-registered jobs. This scenario makes it worth investigating whether there are factors in the Argentine labour market that condition or restrict access to these jobs by certain population groups. One way to do this is to model the probability of obtaining a registered job, which entails focusing on the higher tendency among non-head household members to occupy protected jobs. As analysed in section II, $70 \%$ of the increase in the rate of registration of wage-earning employment reflected what happened to these members.

A two-stage methodological strategy was developed. Firstly, the probabilities of gaining precarious jobs were estimated for the population as a whole; and then the chances of spouses and other members of the household other than the head gaining registered jobs were evaluated.

\section{Views of access to registered jobs}

As noted above, unregistered or precarious jobs are those that do not fulfil employment regulations. Two alternative interpretations can be put forward to explain their existence. The first is that, owing to various circumstances (inability to bear the costs involved in labour regulations or simple evasion), firms decide to hire certain workers without fulfilling the legal obligations. A second explanation focuses on a shift in workers' preferences for these jobs. In this case, it has been argued that flexibility of working hours, the possibility of obtaining higher wages or both, encourage young people and women (groups in which unregistered employment is highest) to choose these occupations. ${ }^{12}$ Nonetheless, it

12 There is a lot of evidence on this (see Perry and others, 2007). should be noted that the available evidence for Argentina supports the hypothesis that unregistered employment is involuntary (see Beccaria and Groisman, 2008).

When the position of persons within households is included in the analysis, it can be argued that the economic activities of household members are related. In particular, some interpretations have claimed that the decision by spouses and children to take a registered or unregistered job is influenced (or conditioned) by the occupational status of the household head, who, as will be recalled, is the main income-earner. ${ }^{13}$ The fact that the head of household has a protected job may provide an incentive for the other household members, if they enter economic activity, to take jobs that are not registered in social security. This would reflect the fact that the household detects that a significant part of the benefits of registration become redundant if more than one member of the family nucleus has a protected job; for example, access by the family group to the benefits of the health or some system of social benefit requires just one of the spouses to contribute to it. Another factor justifying such behaviour is the presumed weak relation between the contribution to social security during the person's active life and the level of pension benefits eventually paid. Similarly, it is also pointed out that unregistered workers are in a better position to negotiate a higher in-pocket wage, in exchange for non-registration by employers. The two latter arguments are also applicable to heads of households.

Nonetheless, from a different perspective than that outlined above, it is also possible to argue for an inverse relation, namely that the probabilities of access to protected jobs by spouses and other family members are greater when heads of household occupy jobs registered with social security. Firms tend to start their search for candidates to fill vacancies through consultation procedures within the productive unit, which, in many cases, reduces search costs and guarantees a closer match between the characteristics demanded and those offered. In this sense, workers who form part of stable payrolls in firms (registered jobs) have privileged access

13 In a related line of research, albeit different than what is being developed here, the specialized literature has also tested the existence of the additional-worker phenomenon (for the case of Argentina, see Paz, 2009). 
to this information, which they then transmit within their household. Moreover, many firms prefer to hire family members of existing workers for various reasons, for example as a way of encouraging commitment to the task, thereby obtaining beneficial effects on competitiveness. Similarly, workers who are unionized (only applicable to those in registered jobs) also tend to have greater access to preferential information on vacancies arising in the economic activity in which they participate. Other arguments can also be made to sustain such a relation. In societies with high levels of social exclusion, the spatial distribution of families is tending to change, causing or intensifying residential socioeconomic segregation. In this case, through a neighbourhood or social-capital effect, or both, the chances of accessing registered jobs would be greater for household members living in urban environments that are better integrated into the productive sector.

Whatever the argument used, it is reasonable to postulate that the occupation of the spouse of the head of household and other family members is an endogenous variable, for which reason the model used should take this constraint into account.

\section{The models used}

The chances of accessing a precarious job need to be estimated using models with a limited or binary dependent variable, with two possible categories: employment in a job that is registered with social security, or employment in a job that is not registered. Unlike linear probability estimations, equivalent standard deviation (probit) models satisfy this condition (see Wooldridge, 2002). equation:

Formally, the model is based on the following

$$
P(y=1 \mid X)=G(X \beta)
$$

Such that $G($.$) takes values in the interval (0.1), in other$ words, $0<G(z)<1$.

The model assumes a normal distribution function and is estimated through the maximum-likelihood method.

$$
G(z)=\int_{-\infty}^{z} \varphi(v) d v
$$

Interpretation of the coefficients requires estimating the marginal effects:

$$
\frac{\partial p(x)}{\partial x_{j}}=g(x \beta) \beta_{j} \text { where } g(z) \equiv \frac{d G}{d z}(z)
$$

In the analysis of the probabilities of non-head household members gaining access to a registered job, potential endogeneity problems need to be considered, so a bivariate and recursive probit model is specified. ${ }^{14}$ Unlike the classical bivariate probit simultaneous equations model, this specification makes it possible to consider the employment of the head of household and other household members as the outcomes of related decisions. The high incidence of unregistered employment among non-head household members, mostly women and young people, suggests that certain aspects of family dynamics have an influence on their greater propensity for precarious employment.

Formally,

$$
\begin{gathered}
y_{1}=\beta_{1} \chi_{1}+\varepsilon_{1} \\
y_{2}=\beta_{2} \chi_{2}+\varepsilon_{2}=\delta_{1} y_{1}+\delta_{2} z_{2}+\varepsilon_{2}
\end{gathered}
$$

where $\chi_{1}$ represents the observable exogenous determinants of the head of household's decision to take a registered job, and $z_{2}$ represents the observable exogenous determinants of the probability that non-head members of the household gain a registered job.

The error terms of equations [4] and [5] are assumed independent and identically distributed as bivariate normal, with zero mean and unit variance, such that $\rho=\operatorname{corr}\left(\varepsilon_{1}, \varepsilon_{2}\right)$. The exogeneity condition can be established in terms of $\rho$, which can be interpreted as the correlation of the unobservable and/or omitted explanatory variables of the two equations. The coefficients of the model as presented can be efficiently estimated using the maximum-likelihood method. From the econometric standpoint, the endogenous nature of $y_{1}$ in the second equation of the model does not alter the likelihood function of a standard bivariate probit; so, unlike what happens in a linear simultaneous equation model, if the two dependent variables are determined jointly, one of them is merely included as the regressor in the other equation (see Greene, 2003).

\section{Variables used and results obtained}

\section{(a) Probit model}

The dependent variable was defined dichotomously, being equal to 1 when the individual worked as a wage

\footnotetext{
14 An example of the application of this methodology to a similar topic can be found in Galiani and Weinschelbaum (2007).
} 
earner in a job that was not registered in social security, and 0 when a registered wage earner. The independent variables included were sex, age, age squared, education (in three categories), position in the household, number of household members, branch of activity, and region of residence. The estimation also included control for selection bias. The variables used for the selection equation were marital status (with or without spouse), number of children in the household, education and age.
The results obtained show that wage earners with a low education level, women, and non-head members of the household are less likely to gain a registered job. Household size also operated in the same direction: the more members, the higher the probability of working in a precarious job. In contrast, as aged increased, this trend decreased, which is consistent with the greater prevalence of unregistered employment among young people (see table 12).

TABLE 12

Estimation of the determinants of precarious employment ${ }^{\mathrm{a}}$

(Total urban agglomerates)

\begin{tabular}{|c|c|c|c|c|c|c|c|c|}
\hline \multirow{2}{*}{$\begin{array}{l}\text { Dependent variable unregistered } \\
\text { employment }=1 \text { and registered } \\
\text { employment }=0\end{array}$} & \multicolumn{4}{|c|}{ Q1 2004} & \multicolumn{4}{|c|}{ Q1 2009} \\
\hline & Coef. & Std. Err. & $\mathrm{P}>|\mathrm{z}|$ & Ef. Marg. & Coef. & Std. Err. & $\mathrm{P}>|\mathrm{z}|$ & Ef. Marg \\
\hline Woman & 0.199 & 0.044 & 0.000 & 0.054 & 0.146 & 0.054 & 0.006 & 0.058 \\
\hline Low education & 1.183 & 0.057 & 0.000 & 0.341 & 0.873 & 0.248 & 0.000 & 0.337 \\
\hline Medium education & 0.455 & 0.050 & 0.000 & 0.113 & 0.292 & 0.153 & 0.056 & 0.116 \\
\hline No head of household & 0.131 & 0.039 & 0.001 & 0.036 & 0.121 & 0.039 & 0.002 & 0.048 \\
\hline Age & -0.107 & 0.012 & 0.000 & -0.029 & -0.112 & 0.014 & 0.000 & -0.045 \\
\hline Age squared & 0.001 & 0.000 & 0.000 & 0.000 & 0.001 & 0.000 & 0.000 & 0.000 \\
\hline Household size & 0.020 & 0.009 & 0.030 & 0.005 & 0.043 & 0.013 & 0.001 & 0.017 \\
\hline $\begin{array}{l}\text { Controls for sector of activity } \\
\text { (dummy variables) }\end{array}$ & Yes & & & & Yes & & & \\
\hline $\begin{array}{l}\text { Controls for region } \\
\text { (dummy variables) }\end{array}$ & Yes & & & & Yes & & & \\
\hline Constant & 2.038 & 0.185 & 0.000 & & 0.993 & 0.491 & 0.043 & \\
\hline
\end{tabular}

Source: Prepared on the basis of EPH-INDEC data.

Variables included in the sample selection equation: married/unmarried, number of children, education and age.

a probit model with sample selection control.

(b) Recursive bivariate probit model

Two models were estimated according to the following scheme:

\section{MODEL 1}

\section{Equation 1}

Dependent variable: spouse registered/ unregistered.

Independent variables: head of household registered; education level of spouse; age and age squared of spouse sex of spouse; household size and presence of children under five years of age.
Equation 2

Dependent variable: head of household registered/ unregistered.

Independent variables: education level of head of household; age and age squared of head of household; sex of head of household; household size and presence of children under five years of age.

\section{MODEL 2}

\section{Equation 1}

Dependent variable: Non-spouse non-head household members registered/unregistered. 
Independent variables: head of household registered; education level of spouse; age and age squared of spouse; sex of spouse; household size and presence of children up to five years of age.

\section{Equation 2}

Dependent variable: head of household registered/ and registered.

Independent variables: education level of head of household; age and age squared of head of household; sex of head of household; household size and presence of children under five years of age.

Both cases involved probability equations estimated through the recursive bivariate probit model, for heads of household and spouses in model 1 and for other household members in model 2. The universe of analysis includes all households composed by both spouses, who are also employed in wage-earning jobs for model 1 . Model 2 included households composed by a head and at least one other (non-spouse) member who were also wage earners. The recursive characteristic of the model stems from the fact that the variable defining the registered/ unregistered wage-earning status of household heads has been included as an independent variable for estimating the same probability for spouses and other household members in each model.

\section{(c) Results}

Table 13 reports the coefficients of the estimated models and the marginal effects of interest for the beginning and end of the period being analysed. The parameters estimated for the independent variables had the expected signs: access to a registered job was greater for individuals with a high education level, males, and as age increased, although the increases were not linear. Moreover, household size and the presence of children under five were variables that reduced the chances of gaining a job with these characteristics.

The most interesting result is that when the household head was employed in a registered wage earning job, the spouse was more likely also to be working in a job of that type. In absolute terms, this was shown by the fact that spouses in households whose heads had a registered job had probabilities between $34.8 \%$ and $41 \%$ higher, for 2004 and 2009, respectively, than those of wage-earning spouses in households whose heads were wage earners in unregistered jobs. The results of the second model confirmed a similar finding for non-spouse household members in 2009, although they were not significant in 2004. In 2009, the likelihood that these household members, basically children, had a protected job was $20 \%$ higher than for those living in households whose heads were wage earners in precarious jobs. 


\begin{tabular}{|c|c|c|c|c|c|c|c|c|}
\hline & \multicolumn{4}{|c|}{ Q1 2004} & \multicolumn{4}{|c|}{ Q1 2009} \\
\hline & Coef. & Std. Err. & $\mathrm{P}>|z|$ & Elast. & Coef. & Std. Err. & $\mathrm{P}>|\mathrm{z}|$ & Elast. \\
\hline \multicolumn{9}{|c|}{$\begin{array}{l}\text { Model } 1 \\
\text { Dependent variable: } \text { Spouse registered }=1 \text { and unregistered }=0\end{array}$} \\
\hline \multicolumn{9}{|c|}{ Dependent variable: Spouse registered $=1$ and unregistered $=0$} \\
\hline Head registered & 0.901 & 0.390 & 0.021 & 0.348 & 1.095 & 0.253 & 0.000 & 0.410 \\
\hline Medium education level & 0.906 & 0.144 & 0.000 & 0.298 & 0.775 & 0.123 & 0.000 & 0.210 \\
\hline High education level & 1.602 & 0.182 & 0.000 & 0.469 & 1.164 & 0.145 & 0.000 & 0.307 \\
\hline Age & 0.107 & 0.044 & 0.015 & 0.039 & 0.061 & 0.030 & 0.039 & 0.019 \\
\hline Age squared & -0.001 & 0.001 & 0.044 & 0.000 & -0.001 & 0.000 & 0.098 & 0.000 \\
\hline Male & -0.064 & 0.198 & 0.748 & -0.023 & 0.188 & 0.136 & 0.166 & 0.055 \\
\hline Household size & -0.081 & 0.038 & 0.033 & -0.029 & -0.062 & 0.034 & 0.067 & -0.019 \\
\hline Children under 5 years of age & -0.022 & 0.122 & 0.855 & -0.008 & -0.047 & 0.100 & 0.641 & -0.014 \\
\hline Constant & -3.424 & 0.830 & 0.000 & & -2.252 & 0.553 & 0.000 & \\
\hline \multicolumn{9}{|c|}{ Dependent variable: Head registered $=1$ and unregistered $=0$} \\
\hline Medium education level & 0.480 & 0.112 & 0.000 & & 0.638 & 0.099 & 0.000 & \\
\hline High education level & 0.931 & 0.145 & 0.000 & & 0.772 & 0.122 & 0.000 & \\
\hline Age & 0.159 & 0.041 & 0.000 & & 0.092 & 0.034 & 0.007 & \\
\hline Age squared & -0.002 & 0.000 & 0.000 & & -0.001 & 0.000 & 0.007 & \\
\hline Male & 0.302 & 0.193 & 0.118 & & 0.533 & 0.128 & 0.000 & \\
\hline Household size & -0.044 & 0.035 & 0.210 & & -0.034 & 0.033 & 0.309 & \\
\hline Children under 5 years of age & 0.065 & 0.118 & 0.582 & & 0.063 & 0.106 & 0.555 & \\
\hline Constant & -3.357 & 0.835 & 0.000 & & -2.028 & 0.691 & 0.003 & \\
\hline Rho & -0.223 & 0.250 & & & -0.493 & 0.151 & & \\
\hline
\end{tabular}

Model 2

Dependent variable: Spouse registered $=1$ and unregistered 0

\begin{tabular}{|c|c|c|c|c|c|c|c|c|}
\hline Head registered & 0.554 & 0.359 & 0.123 & 0.182 & 0.523 & 0.259 & 0.044 & 0.200 \\
\hline Medium education level & 0.485 & 0.104 & 0.000 & 0.181 & 0.607 & 0.089 & 0.000 & 0.239 \\
\hline High education level & 1.200 & 0.173 & 0.000 & 0.446 & 1.077 & 0.155 & 0.000 & 0.376 \\
\hline Age & 0.013 & 0.005 & 0.009 & 0.005 & 0.009 & 0.004 & 0.030 & 0.004 \\
\hline Age squared & 0.000 & 0.000 & 0.058 & 0.000 & 0.000 & 0.000 & 0.457 & 0.000 \\
\hline Male & 0.266 & 0.094 & 0.005 & 0.099 & 0.173 & 0.079 & 0.030 & 0.069 \\
\hline Household size & -0.234 & 0.067 & 0.001 & -0.088 & -0.213 & 0.049 & 0.000 & -0.085 \\
\hline Children under 5 years of age & 0.242 & 0.167 & 0.148 & 0.093 & 0.257 & 0.112 & 0.022 & 0.102 \\
\hline Constant & -0.921 & 0.216 & 0.000 & & -0.571 & 0.197 & 0.004 & \\
\hline \multicolumn{9}{|c|}{ Dependent variable: Head registered $=1$ and unregistered $=0$} \\
\hline Medium education level & 0.499 & 0.109 & 0.000 & & 0.539 & 0.094 & 0.000 & \\
\hline High education level & 0.688 & 0.188 & 0.000 & & 1.190 & 0.148 & 0.000 & \\
\hline Age & 0.153 & 0.027 & 0.000 & & 0.134 & 0.023 & 0.000 & \\
\hline Age squared & -0.002 & 0.000 & 0.000 & & -0.001 & 0.000 & 0.000 & \\
\hline Male & 0.619 & 0.096 & 0.000 & & 0.693 & 0.081 & 0.000 & \\
\hline Household size & 0.019 & 0.024 & 0.430 & & -0.057 & 0.020 & 0.005 & \\
\hline Children under 5 years of age & -0.448 & 0.113 & 0.000 & & -0.028 & 0.100 & 0.778 & \\
\hline Constant & -3.784 & 0.602 & 0.000 & & -3.236 & 0.544 & 0.000 & \\
\hline Rho & -0.082 & 0.240 & & & -0.118 & 0.167 & & \\
\hline
\end{tabular}

Source: Prepared on the basis of EPH-INDEC data.

a recursive bivariate probit models. 


\section{VI}

\section{Final comments}

The characteristics of Argentina's economic recovery provide a favourable scenario for exploring the relation between the functioning of the labour market and changes in households' social situation. Following the 2002-2003 biennium, when the level of production prevailing in early 2001 had almost been regained, the economy continued to grow vigorously. Job creation and wage increases were two of the pillars on which this expansionary phase was based. In addition, as a distinctive feature in the economic history of the last three decades, there was an intensive increase in jobs registered with social security. In the five years between 2004 and 2009, those high-quality jobs grew faster than unregistered jobs, which resulted in a significant reduction in the rate of precarious employment. Accordingly, the social outlook improved in line with the labour market trend.

A classification of households based on the type of labour-market participation by their members provides an approach to this phenomenon. Using this procedure, it was estimated that the population living in households that basically rely on the employment of their members and do not have wage earners registered in social security decreased from $36 \%$ to $26.1 \%$. Although the improvement was considerable, it is hard deny that quality-employment remained elusive for a large group of people.

Part of the explanation from the persistence of households whose members did not gain protected jobs is to be found in the type of employment activity they undertake. It should be remembered that indices of unregistered employment - despite improvements in the registration of employment relations observed during the five-year period - are generally very high in certain sectors of activity - such as domestic service, construction and commerce- where workers from lower-income households are more heavily concentrated.

The segmentation prevailing in the distribution of job opportunities would also have operated in the same direction. In fact, most households obtain their monetary income from a single employment source, in other words from just one category of labour-market participation: as non-wage earners, registered wage earners or unregistered wage earners. This is compatible with the effect that labour-market participation by the main income earner would have on the job opportunities of other household members. In particular, a new finding in this study is that the increase in registration was very intense among non-head household members - spouses and children basically. The change in the registration rate between 2004 and 2009 reflected this to a significant degree. It was also found that the chances of these household members obtaining a registered job was affected by the employment status of the head of household: members of households whose heads were in a job registered with social security were more likely to gain a higher-quality job themselves.

The results obtained are compatible with the persistence of a social structure that is segmented on the basis of the type of labour-market participation achieved by individuals - basically whether or not they gain access to registered wage-earning jobs. That diagnostic reduces the validity of the assumption that the mere passage of time, given certain macroeconomic fundamentals, will gradually correct these inequities. This opinion is based on the magnitude of the quality employment deficit still observable in Argentine society. It should be noted that $45 \%$ of the urban employed consists of unregistered wage earners and nonprofessional self-employed workers (Permanent Household Survey (EPH) of the National Institute of Statistics and Censuses (INDEC), 2010). In fact, it can be speculated that although the economic conditions for an expansion of registered employment may be maintained in the short and medium terms (competitive exchange rate, high international prices for commodity exports, stimulus to domestic consumption, among others), specific policies will be needed to facilitate access to these jobs by individuals that have failed to avoid precarious employment.

Key measures among these policies aim to reduce indices of unregistered employment in the economic sectors that employ the lowest-income workers, namely domestic service, construction and the retail trade. Moreover, the intensification of procedures for regularizing employment in larger firms could help reduce precariousness in these economic units. The low activity rate in the poorest households also suggests the need for policies that help adult household members to fully engage with the labour market, by discouraging the acceptance of precarious jobs. In this regard, upgrading job skills among lower skilled workers, providing quality childcare centres, and improving communication channels and access to and from the neighbourhoods in which low-income households live have been shown to 
have positive effects. Of course, these initiatives need to be supported by policies to stimulate labour demand, for which incentives for productive units to locate in those spatially segregated zones would be highly recommendable. Lastly, it should be noted that in moving towards a fairer society in terms of job opportunities, income-transfer policies have proven suitable mechanisms for sustaining welfare levels among households that are unable to obtain quality jobs.

(Original: Spanish)

Bibliography

Arriagada, I. (comp.) (2007), "Familias y políticas públicas en América Latina: una historia de desencuentros", Libros de la CEPAL series, No. 96 (LC/G.2345-P), Santiago, Chile, Economic Commission for Latin America and the Caribbean (ECLAC). United Nations publication, Sales No. S.07. II.G.97.

Beccaria, L. and F. Groisman (2008), "Informalidad y pobreza en Argentina”, Investigación económica, vol. 67, No. 266, Mexico City, National Autonomous University of Mexico.

Cetrángolo, O., D. Heymann and A. Ramos (2007), "Macroeconomía en recuperación: la Argentina post-crisis", Crisis, recuperación y nuevos dilemas. La economía argentina 2002-2007 (LC/ W.165), B. Kosacoff (comp.), Buenos Aires, ECLAC office in Buenos Aires.

Devicienti, F., F. Groisman and A. Poggi (2010), "Are informality and poverty dynamically interrelated? Evidence from Argentina”, Research on Economic Inequality, vol. 18, Bingley, Emerald.

Galiani, S. and F. Weinschelbaum (2007), "Modeling informality formally: households and firms", Working Paper, No. 47, La Plata, Center for Distributive, Labor and Social Studies (CEDLAS).

Goldín, A. (2008), "Normas laborales y mercados de trabajo argentino: seguridad y flexibilidad", Macroeconomía del desarrollo series, No. 74 (LC/L.2985-P), Santiago, Chile, Economic Commission for Latin America and the Caribbean (ECLAC). United Nations publication, Sales No. S.08.II.G.91.

Greene, W.H. (2003), Econometric Analysis, New Jersey, Prentice Hall.

Groisman, F. (2010), "La persistencia de la segregación residencial socioeconómica en Argentina", Estudios demográficos y urbanos, vol. 25, No. 2, Mexico City, El Colegio de México.
(2008), "Distributive effects during the expansionary phase in Argentina (2002-2007)", CEPAL Review, No. 96 (LC/G.2396-P), Santiago, Chile.

ILO (International Labour Organization) (2009), World of Work Report 2009. The Global Jobs Crisis and Beyond, Geneva.

ILO/UNDP (International Labour Organization/United Nations Development Programme) (2009), Trabajo y familia: hacia nuevas formas de conciliación con corresponsabilidad social, Santiago, Chile.

Kaztman, R. (2007), "La calidad de las relaciones sociales en las grandes ciudades de América Latina: viejos y nuevos determinantes, Revista pensamiento iberoamericano, Madrid.

Márquez and others (comps.) (2007), ¿Los de afuera? Patrones cambiantes de exclusión en América Latina y el Caribe, Washington, D.C., Inter-American Development Bank.

Paz, J. (2009), "El efecto del trabajador adicional. Evidencia para Argentina (2003-2007)", Cuadernos de economía, vol. 46, Santiago, Chile, Catholic University of Chile.

Perry, G. and others (2007), Informality: Exit and Exclusion, Washington, D.C., World Bank.

Sabatini, F. and I. Brian (2008), "La segregación, los guetos y la integración social urbana: mitos y claves", Eure, vol. 34, No. 103, Santiago, Chile, Catholic University of Chile.

Stallings, B. and J. Weller (2001), "Employment in Latin America: cornerstone of social policy", CEPAL Review, No. 75 (LC/ G.2150-P), Santiago, Chile.

Tokman, V. (2006), "Inserción laboral, mercados de trabajo y protección social", Financiamiento del desarrollo series, No. 170 (LC/L.2507-P), Santiago, Chile. United Nations publication, Sales No. S.06.II.G.39.

Wooldridge, J.M. (2002), "Discrete response models", Econometric Analysis of Cross-section and Panel Data, Cambridge, Massachusetts, The MIT Press. 